\title{
1. Introduction: from bottom-up and top-down towards multi-level governance in Europe
}

\author{
Jan W. van Deth and William A. Maloney
}

As every small-town politician knows, strengthening democratic decisionmaking processes is not an easy matter - most citizens are hard to motivate to engage in public policy debates. And as every small-town politician or local political entrepreneur knows, most citizens are also unwilling to engage actively in the formal or institutionalised political life of their communities. On both counts citizens can find better things to do with their time. Simultaneously however, there are a wide variety of groups and associations actively seeking to advance their specific interests. When we look to more complex political systems like major cities, regions, states and national states we find these polities are 'plagued' by the virtually unsolvable problems and dilemmas that come with any serious attempt to base political decisions on the active engagement of citizens and citizens' organisations. Finally, if we travel one further political level to the multi-layer system of the European Union (EU) - the central focus of this volume - then finding a solution looks like a 'lost cause' before we have even truly begun our search. Put simply and logically, the more numerous the governmental tiers, the further decision-making processes are from citizens, the weaker their potential influence and the smaller the 'incentives' to participate. ${ }^{1}$

Given the above, how does the EU seek to involve citizens more fully and to increase identification with its political institutions? How does the EU seek to improve the transparency, legitimacy and accountability of decision-making procedures? These questions have become central in the enlarged EU. With the continuing expansion of the Union, a complex system of national, sub-national, international, trans-national and supranational institutions has emerged with multiple recursive linkages. In other words, political decision making within Europe is increasingly characterised by the further development of Europeanisation (see Graziano and Vink, 2007). Two approaches ('top-down' and 'bottom-up') can be used to analyse the increasingly complex and interdependent relationships in this 
area. The traditional Truman (1951) demand-side or bottom-up approach that relies on the initiative of citizens to act spontaneously in the face of a political threat or to advance a common interest through organisational mobilisation faces many barriers. And even if such mobilisations are successful, it is likely that in many cases it would take a long time before such voices were audible to EU decision makers - if they were heard at all! For these reasons, the European Commission instigated several top-down approaches, trying to stimulate the active involvement of civil society organisations, most notably citizen groups, in EU decision-making processes. As Greenwood (2007: 343) highlights, the Commission has played an 'active role in funding regimes for citizen interest groups and in empowering citizen interest groups through (various) policy initiatives'.

Although the links between civil society and democracy have been established at the local and national level, not much is known about the extent to which associations contribute to European integration or the functioning of democracy at the (complex) EU level. How do local and national associations empower civic actors to 'get engaged' in the European and/or international arena? Are there positive or negative feedback loops? Do civil society organisations at various levels contribute to good governance in terms of democracy and efficiency?

\subsection{CIVIL SOCIETY AND MULTI-LEVEL GOVERNANCE: THE DEMOCRATIC CHALLENGE}

Civil society is now at the core of EU thinking on bridging the 'democratic deficit'. ${ }^{2}$ The European Commission increasingly refers to civil society and social capital in order to promote good governance in terms of democracy, accountability and efficiency. As Saurugger (2007: 388) reminds us, organised civil society is attractive to policy makers because it is a 'product of the right of free association' and these bodies are primarily seen 'as bottom-up, citizen-initiated phenomena, part of the voluntary process of people's coming together to govern themselves'. Civil society is seen as comprising a vast number of associations such as interest groups, voluntary associations, social movements, social movement organisations, non-governmental organisations (NGOs), clubs, political initiatives, foundations and so on. At the EU level, many of these associations are large; more crucially however, they are also 'supposed' to be encompassing and representative, with grassroots involvement and an accountable leadership (Saurugger, 2007: 388). The EU believes that such a 'civil society' could and should play a major role in increasing the density, diversity, breadth and 
depth of the links between citizens and decision makers in Europe. ${ }^{3}$ As Warleigh (2001: 620) notes, 'Civil society has been championed by both right and left' as a means to either 'defeat "big government", or bring citizens back in, and there is a broad consensus among EU policy makers 'that a greater role for civil society must be a central feature of European governance in the future'.

Accordingly, the EU White Paper on Governance (Commission of the European Communities 2001) issued a rallying call for a more engaged and vibrant European civil society, not as a desirable add-on, but an urgent and immediate necessity. In its decision to establish a 'Community action programme to promote active European citizenship (civic participation)' the Council of the European Union specified as one of the main objectives its aim 'to bring citizens closer to the European Union and its institutions and to encourage them to engage more frequently with its institutions'. Besides, all kind of 'civil society bodies' are invited to specify their needs for support to become actively involved in reaching these goals. ${ }^{4}$ These formulations reflect the much more general goals formulated in the White Paper. Thus the Commission aimed to make the policy-making process in Europe more open, transparent and participatory, and involve a wider range of actors in it from varying institutional and territorial levels - that is, from Eurogroups to local groups. The key objective is to encourage citizens 'to engage more frequently with its institutions . . . [and] to stimulate initiatives by bodies engaged in the promotion of active and participatory citizenship' (Commission of the European Communities 2001). However, as Friedrich (2007: 6) argues, the modern perspective on encouraging a more participatory democracy is no longer rooted in the classic democratic theory (of Rousseau or Mill) 'about the participation of individuals . . . [S]ince the 1960s (Blühdorn 2007), the term participatory democracy is increasingly used together with participatory governance, referring to the participation of collective actors of the organised civil society'. He further notes, as does the Commission, that civil society is not a panacea for all the democratic pathologies associated with the European policy-making process. Civil society does, however, open 'the possibility for thoughts about additional, complementary institutionalisations that are capable of rendering policy-making process more democratic which cannot (and perhaps even should not) rely predominantly on representative mechanisms' (Friedrich, 2007: 9).

The EU White Paper on Governance (Commission of the European Communities 2001) should also be set in the context of the post-Putnam social capital debate that (re-)emphasised the importance of the internal aspects of associational life for the proper functioning of democracies and societal integration. Working in the spirit of Alexis de Tocqueville, many 
authors have stressed the importance of civil society for the proper functioning of democratic political systems. In his seminal work on Italy, Putnam concluded: 'Good government in Italy is a by-product of singing groups and soccer clubs' (1993: 176). Consequently, the problems encountered by many democracies are - at least partly - the result of a decline in membership of many types of associations, clubs, groups and organisations; that is, a decline in civil society (Putnam, 1995, 2000). Claims made about the benevolent aspects of civil society and social capital are not restricted to 'good government' and they are not modest. To quote Putnam once more: 'social capital makes us smarter, healthier, safer, richer, and better able to govern a just and stable democracy' (Putnam 2000: 290). Notwithstanding the attractiveness of the social capital concept and the lines of reasoning, it is clear that even the most evangelical adherent would not consider it to be a panacea for all democratic pathologies. What is widely accepted, however, is the notion that modern democracies are dependent on an active and vibrant civil society and a healthy stock of social capital. In the current epoch (and from the Commission's perspective) groups are seen as delivering for democracy on two main counts (and several other subsidiary but important ways). First, they are perceived as (effective) representative vehicles delivering public policy outcomes that match citizens' preferences. Second, the internal social capital experiences within groups are seen as democratically crucial. In general, groups are seen as generating the pro-democratic values that bolster democracy and, in the specific EU context, they have the potential to enhance the quality of the political linkage between citizens and decision makers. Additionally, they may even increase citizens' attachment to, trust and confidence in, and identification with, the EU and European institutions among citizens across Europe (compare Noll and Scheuer, 2006).

However, even a cursory glance at the 'standard operating procedures' of the decision-making process in Brussels or Strasbourg would make even a mild sceptic perceive the general recommendation to mobilise more associations as little more than laudable but symbolic rhetoric. According to the Commission, about 2600 lobbying groups and over 15000 representatives of various groups are active in Brussels alone. Interestingly, and importantly for the normative aspects of the civil society debate outlined above, the distinction between the lobbying activities of commercial bodies and interest groups on the one hand, and activities of non-profit associations with more general concerns on the other, has gradually been eroded by the rise of so-called non-governmental organisations (NGOs) - a new type of association which places itself explicitly between authorities or institutions and the citizenry. The result of these various developments is the formation of a 'lobby-cracy' consisting of 'merchants of influence' offering a mixture 
of conventional lobbying and more up-to-date forms of politicking. ${ }^{5}$ As Saurugger (forthcoming 2009), Michalowitz (2004), Sudbery (2003) and Warleigh (2001) have argued, NGOs cannot really be viewed as normatively superior to 'grubby' old-fashioned interest groups (see below for a more detailed discussion). Accordingly, the challenge for democratic decision making cannot solely focus on an unconditional increase in the role and competences of various groups. It must take into account the specific developments of the interactions between decision makers and interest groups in Europe and both the changing nature of citizen mobilisation and citizen involvement in the policy-making process.

For example, chequebook participation is widely accepted by many citizens. Besides, it is seen by groups as the most efficient way to mobilise and more crucially from a civil society perspective - many citizens see such limited involvement as attractive. As Jordan and Maloney (2007: 160-61) note, on the demand-side, most members or supporters 'are content to embrace a politically marginal role and contract-out their participation' to groups and many do not see membership of groups as a means of being 'active in politics'. Indeed, quite the reverse. Many citizens perceive passive involvement as a 'benefit' and would consider leaving organisations that sought to impose the 'cost' of active involvement in group activities. ${ }^{6}$ In his study of NGOs in the development policy area, Warleigh (2001: 623) found that these bodies were staff-dominated and made 'little or no effort to educate their supporters about the need for engagement with EU decisionmakers . . . Moreover - and perhaps more worryingly - I found no evidence that supporters are unhappy with this passive role, displaying at best little interest in the EU as a focus of campaigning or locus of political authority' ${ }^{7}$ Later he notes that several group leaders conceded that a lack of membership 'participation was a problem for their credibility' (Warleigh, 2001: 634). Sudbery (2003: 89) quoted a Senior Policy Officer, European Platform of Social NGOs, as stating that 'we do not have direct contact with supporters, but rely on member organisations to bring the issues to our attention'. She (2003: 90) also found that with limited resources, groups preferenced 'effective results' over raising awareness. A senior representative of the European Environment Bureau (EEB) said that 'While ideally it would be good to get people involved ... my role is not to encourage the most participatory governance, but to ensure the best results for the environment'. Even members of the European Commission Governance team were candid about the tension between efficiency and citizen participation. 'We simply do not have the resources to deal with all civil society organisations ... Perhaps the most effective way to link with the citizen . . . is by more effective results ... The issue about bringing in the citizen is for speeches, for the rhetoric' (Sudbery 2003: 91f). 
From the group perspective, the best way to produce effective results clearly has a significant impact on the nature of the 'demands' it makes of its membership. There are clearly tensions - felt by groups and policy makers - between democratic efficiency and more participatory modus operandi. This of course is a generic problem not confined to the political system of the EU. Crenson and Ginsberg (2002: 147) argue that in the US the new politics of policy making advantages expertise and technical knowledge over the mobilisation of large numbers of citizens. As they conclude, this new politics is open " to all those who have ideas and expertise rather than to those who assert interest and preferences". Those admission requirements exclude the great mass of ordinary citizens'. Similarly, Chaskin (2003) - who focused on attempts at fostering neighbourhood democracy - highlighted the importance of expertise and argued that this was partly driven by the professionalisation of public agencies. Skocpol (2003: 134) summarises the recent general trends:

the very model of what counts as effective organization in US politics and civic life has changed very sharply. No longer do most leaders and citizens think of building, or working through, state and nationwide federations that link faceto-face groups into state and national networks. If a new cause arises, entrepreneurs think of opening a national office, raising funds through direct mail and hiring pollsters and media consultants . . . Organizational leaders have little time to discuss things with groups of members.

Directly at the EU level, Saurugger (2007: 397) more than hints at the tension that exists between being representative, responsive and accountable on the one hand and acting as an efficient policy-making partner on the other. The more efficient groups are:

representing their interests in a constructive, precise and coherent manner, the more influence they exert. These activities, however, require major expertise on the group's and movement's side which contributes to modeling the style of militancy and leads to greater internal professionalization. Thus, the organizational structures of civil society have reformed to match better the perceived access structure of the European political system . . . Organized civil society - organized as groups or social movements - has a tendency to become increasingly professionalized to represent the interests of their constituency in an efficient way (Saurugger 2007: 397-398). ${ }^{8}$

Notwithstanding the scepticism above, the EU has provided significant levels of funding to many civil society organisations. At least the Commission could credibly argue that laudable rhetoric has also been matched by significant financial commitment. As Greenwood (2007: 343) notes 'the Commission's role in stimulating the emergence of citizen interest groups, and in funding 
and nurturing them ... really catches the eye'. It spends approximately 1 per cent ( $€ 1 \mathrm{bn})$ on funding groups and almost the entire (300) citizen interest group universe (excluding Greenpeace) mobilised at the EU level receives some EU funding. Some groups are close to being almost entirely solvent on the basis of EU money (for example, 80-90 per cent of the funding of the European Network Against Racism and the European Social Platform comes from EU institutions and Social Platform organisations receive 60-90 per cent of their funding from EU sources) (Greenwood 2007: 343f). Without being mean spirited, this funding is not all aimed at extending participatory democracy and 'bringing citizens in', and in some respects such patronage can be seen as counterproductive. First, some funding is designed to engender lobbying that will strengthen the bargaining positions of DGs. Greenwood (2007) cites Bauer's (2002) example of the DG Employment, Social Affairs and Equal Opportunities (DG EMP) and the European Anti-Poverty Network relationship as a 'lobby sponsorship'. Bauer (2002) presented this as a case of the Commission 'creating its own constituencies with the clear intention of raising support for particular policy solutions and, thus, of influencing deliberations and indirectly setting political priorities' (Bauer 2002: 389; cited in Greenwood 2007: 344). Secondly, there is also a negative externality to patronage - it can obviate the need for members. ${ }^{9}$ If institutional sources are prepared to fund organisations to operational levels of 80-90 per cent, then members become a luxury, or as Skocpol (2003: 134) acerbically put it 'Members are a nonlucrative distraction'. Why spend a great deal of organisational resources seeking and servicing members, when patronage permits fully focused professional lobbying?

\subsection{THE HORIZONTAL AND VERTICAL DIMENSIONS}

It is clear from the discussion above that establishing and improving democratic decision-making processes at the EU level is not straightforward. At the core of these debates are links between groups and institutions at various levels in Europe. As outlined, this dimension can be analysed in two directions: top-down (that is, the consequences of Europeanisation for civil society at national or regional levels) and bottom-up (that is, the consequences of civil society for the process of European integration and democratic governance in the EU). The exploration of these recursive linkages requires a rethinking of the relationships between (local, regional, national and trans-national) civil society on the one hand, and multi-level governance at the European level on the other. ${ }^{10}$ In addition to this, the key role that NGOs play in the various links between the conventional sub-national 
levels and the trans-national level has to be analysed. By dealing with the roles and functions of NGOs, the crucial problems and prospects of democratic decision-making processes in complex multi-level systems become evident.

As noted above, the average citizen is somewhat distant from EU institutions. This is illustrated in the schematic overview of relationships in a multi-level system of governance in Europe (Figure 1.1). It is also evident in such a rudimentary scheme that a number of relationships exist between: (i) citizens and activists within all kinds of civil society associations; (ii) these associations and other associations at other levels (local, regional and so on); (iii) these associations and national state institutions; (iv) these associations and 'their' European federations active at the EU level; and

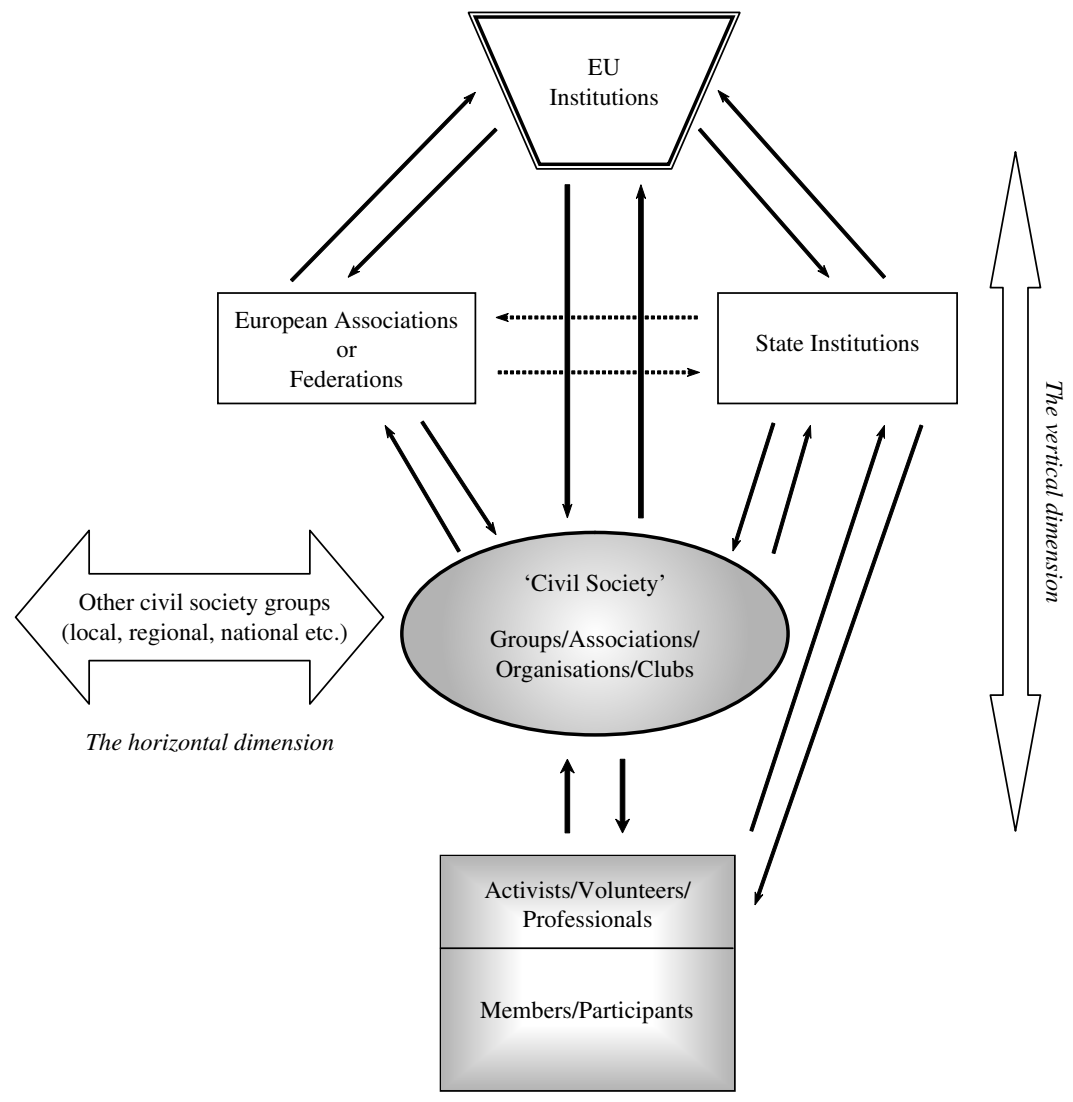

Figure 1.1 A schematic overview of relationships in a multi-level system of governance in Europe 
(v) these associations and EU institutions. ${ }^{11}$ Two dimensions can be discerned in this network of relationships vis-à-vis civil society associations. First, a horizontal dimension entails the relationships between various actors at the same level: in Figure 1.1 the relationships between associations and other associations - for example between sports clubs and youth clubs in some region - are depicted as horizontal relations. In general, the horizontal dimension consists of cross-sectional relationships such as connections between associations, or between regions or local communities, or between state governments. Although these relationships are worthy of study and generate some interesting research questions, this dimension is of limited analytical value for our purposes because greater inclusion in European decision-making processes is difficult to attain here. The second, vertical dimension is more relevant for our focus and consists of all the relationships between actors at different levels irrespective of the specific nature of these contacts or the relevant actors. Of the five main relationships outlined above, the second example (ii) refers directly to the horizontal dimension; the rest can be seen as cases on the vertical dimension.

In the bottom-up approach, the relationships between the various actors on the vertical dimension that begins with the individual citizen are followed. Direct links between citizens and EU institutions are very rare beyond voting for the European Parliament or possibly obtaining information on EU regulations and procedures. The indirect links via national institutions or civil society associations appear more important. State institutions represent the 'national' interests of citizens and civil society associations offer opportunities to represent the wishes and demands of particular areas such as sports, safety regulations or cultural exchanges. Given that national and area-specific interests are not mutually exclusive, many associations have founded European associations or federations that unite various national interests in specific areas. These national and European entities might engage in a competitive struggle for resources at the European level or they may join forces to further their common interests' vis-à-vis EU institutions. From a bottom-up perspective, voluntary associations and national institutions appear as linkages, transmitters, amplifiers or barriers in the relationships between citizens and decisionmaking processes at the EU level.

On the vertical dimension, a top-down approach starts with high-level decision-making processes. Political themes and issues originate and are defined by the actors involved in decision making at the EU level. Linkages with national institutions, associations and federations of voluntary associations are highly relevant since they conceal the interdependencies and powers of various actors. By mobilising these institutions and associations, demands and interests can be strengthened. Information is transmitted 
from arenas in Brussels and Strasbourg to actors not directly involved in decision-making procedures at that level. As with the bottom-up perspective, the top-down perspective locates citizens at some distance from decision-making processes. In a similar way, voluntary associations and national institutions can be seen as linkages, transmitters, amplifiers or barriers in the relationships between decision-making processes at the European level and individual citizens. It was on this basis that the European Commission launched its plan to increase citizens' engagement in European affairs through voluntary associations as representative and participatory vehicles, as indicated in the White Paper.

While the top-down and bottom-up directions on the vertical dimension are clearly very different, they share the assumption that national institutions, associations and federations of voluntary associations play a crucial linkage role between citizens and decision-making processes at the European level. Furthermore, the two perspectives see these intermediary actors as playing similar roles by either strengthening and encouraging these linkages (by articulating and transmitting demands or by channelling information) or by frustrating the relationships (by filtering, manipulating or stopping demands and information). National institutions, associations and federations of voluntary associations, then, form the main objects when researching the challenges facing democratic decision-making processes in the EU.

\subsection{THE ROLES AND FUNCTIONS OF NGOS}

Akin to many other social science research areas, there are several normative debates and other controversies centring on civil society and the role of groups, organisations and associations, especially NGOs. What should be the proper role of civil society or NGOs in a democratic system? What functions do civil society or NGOs actually perform in specific democratic systems? There are, of course, the almost obligatory definitional, labelling and counting debates surrounding the distinguishing characteristics of the entity, the accuracy of the labels we attach to certain phenomena and the question of which type of bodies qualify as belonging to civil society or the NGO sector and how they are distinctive from other kindred (sometimes almost identical) phenomena. In some cases the labels chosen are used by scholars to indicate some normative desirability (or pathology). Thus labelling an organisation as an NGO rather than an 'interest' or 'pressure group' or part of some 'lobby' may accord it a more normatively desirable status. As Grant (2002: 5) highlights, 'civil society' - of which NGOs are a key component can be seen as providing a positive conferral of greater legitimacy on what 
others might perceive as an interest group system. In this respect, interest groups might be viewed as democratically damaged goods and NGOs as democratically superior vehicles. However, in many cases empirical research uncovers greater commonality than the diversity suggested by the labelling. Friedrich (2007: 11) cites Nanz and Steffek's (2005: 382) deliberativetradition type of definition of a civil society organisation as:

a non-governmental, non-profit organization that has a clearly stated purpose, legal personality and pursues its goals in non-violent ways. Apart from activist organizations this definition includes social partners (i.e. trade unions and employers associations), consumer associations, charities, grass roots organizations and religious communities.

As Friedrich (2007: 12) argues, 'On purely empirical grounds there seems to be no reason not to call these organizations "interest groups" as pluralists would probably do'.

The Commission's (2000: 3 ) discussion paper on NGOs struggled to find a 'common definition' and described the sector as 'extremely diverse, heterogeneous and populated by organisations with hugely varied goals, structure and motivations'. Nevertheless, the paper argued that the NGO term could be seen as shorthand for entities that shared certain characteristics: non-profit-making, voluntary, independent, a formal body with some sort of constitution that is accountable to members and/or donors, and not rent-seeking - that is, not in pursuit of sectional interests, such as 'the commercial or professional interests of their members' (Commission of the European Communities 2000: 4). In addition to this, NGOs vary in size (a handful of members to hundreds of paid staff and millions of members) and scope (advocacy and service delivery). ${ }^{12}$ Similarly Grant (2002) also noted that the United Nations (UN) states that NGOs must have aims and purposes in conformity with the spirit, purposes and principles of the UN Charter; a formal organisation and a democratically adopted constitution; and appropriate mechanisms of accountability (UN Regulation 1996/31 quoted by Grant 2002: 2). Grant points out that, in practice, sectional and business groups are widely accredited as NGOs and he cites Scholte (1999: 171), who claims that 65 per cent of 'civic organizations' at the Singapore Conference of the World Trade Organization (WTO) were business-based (also see Saurugger forthcoming 2009, Michalowitz 2004, Sudbery 2003 and Warleigh 2001). ${ }^{13}$

The Commission sees NGOs as contributing to EU democracy on a number of fronts. ${ }^{14}$ First, 'fostering a more participatory democracy' (Commission of the European Communities 2000: 4). Associational membership provides citizens with a means of participating beyond the confines of elections, political parties and trade unions. They can also act as 
Tocquevillian schools of democracy, facilitating the development of prodemocratic values and social integration, and they can also be significant generators of social capital. NGOs are a valuable prop for democracies and are increasingly becoming involved in the policy-making process. Second, representing specific groups (such as pensioners, disabled, ethnic minorities) and interests (such as environment, human rights, animal welfare). NGOs are seen as being able to act as a counterbalance to other societal interests and 'to reach the poorest and most disadvantaged and to provide a voice for those not sufficiently heard through other channels' (Commission of the European Communities 2000: 5). Thus advocacy and counterbalancing advocacy are seen as important attributes, and groups also have a significant surrogate function - that is, they act on behalf of a public that lack the necessary political resources (for example, children or those with specific mental health problems). Much group activity seeks to advance many causes that benefit constituencies and interests beyond the direct interests of participators (for example, human rights, poverty, debt relief). Third, NGOs through their expertise and links at local, regional, national and European levels can contribute directly to the policy-making process and also monitor policy implementation by providing some feedback or evaluation. Fourth, NGOs can contribute to project management by 'monitoring and evaluating projects financed by the EU' (Commission of the European Communities 2000: 5). Finally, they are seen as contributing to European integration 'in a practical way and often at the grassroots level' (Commission of the European Communities 2000: 5). National and European level networks of NGOs help shape 'European public opinion'. The Commission also valorises NGOs as enhancing political linkage and political representation and as vehicles of self-government.

\subsection{THE PLAN OF THE BOOK}

The contributors to this volume analyse the opportunities for voluntary associations to contribute to European integration and decision making from various perspectives. The two main approaches - bottom-up versus top-down - are represented in the first part on 'Civil Society and Voluntary Associations', and in the second part on 'Interest Mediation and Decision Making', respectively. Before the results of these approaches are presented, Annette Zimmer and Matthias Freise discuss the main similarities and distinctions between the central concepts of civil society, social capital and the third sector (Chapter 2). According to their conceptualisations, the various actors should be discerned on the basis of a distinction between so-called civil society associations and third-sector organisations. 
The first part of the volume consists of five contributions dealing with bottom-up perspectives on the relationships between citizens and citizens' organisations and political decision-making processes. As highlighted above, the Commission's valorisation and embracing of civil society was also aimed at increasing European citizens' trust and confidence in, and identification with, Europe and European institutions. The level of confidence in these institutions is usually low (see Maloney and van Deth, Chapter 3). Maloney and van Deth start this part with an analysis of orientations towards Europe among activists and volunteers of all kinds of voluntary associations in Aberdeen and Mannheim. Marc Hooghe expands the scope by explicitly considering the political opportunity structure for civil society organisations in Europe (Chapter 4), whereas Deborah Cook focuses on attempts to strengthen the links between citizens and Europe by analysing the role of these organisations in the discussions on the European Convention in Wales (Chapter 5). Christina Parau and Jerry Wittmeier Bains study the role of domestic actors in complex decision-making processes in Britain and the Czech Republic (Chapter 6). The first part is concluded by Didier Chabanet and Marco Giugni, who compare the various ways in which migrants and unemployed people try to articulate their claims (Chapter 7).

The four contributions to the second part of the volume deal with topdown perspectives and focus on interest mediation and decision making. The development of a European 'political space' is analysed by Cécile Leconte on the basis of her study of the gatekeeping role of national party elites (Chapter 8). Policy making and the role of associations form the topic of the next two contributions. Christine Mahoney presents the results of her research on lobbying groups and discusses the role of interest groups in fostering citizen engagement (Chapter 9). The cake is cut in a different way by Silke Adam, Margit Jochum and Hanspeter Kriesi in their extensive analyses of the development of policy networks in several policy domains in various countries (Chapter 10). The most explicit attempts to introduce top-down approaches are presented by Susan Stewart in her discussions of EU support for civil society in the Baltic states (Chapter 11).

In the concluding chapter, William Maloney and Jan van Deth return to the initial question of multi-level governance and Europeanisation (Chapter 12). The research has demonstrated that the Europeanisation process in terms of civil society actors adapting to the European political space had a somewhat uneven development. Some of the main empirical findings include:

- engagement with and confidence in the EU (compared to national institutions) is relatively weak among the group of citizens that the social capital model predicts would be highest - associational members; 
- party elites play a key gatekeeper role in the European space;

- the EU is having a limited success in stimulating the development of civil society and social capital in the Baltic states;

- interest groups - in 'their' role as intermediary associations - have not been particularly successful in fostering citizen engagement.

The social capital being generated within the European space is nationcentred: that is, values and trust are heavily oriented towards national societies and political systems. Consequently, there appears to be a deficit in the stock, or variety, of social capital required that could contribute to 'good' EU governance and enhance political legitimation.

\section{NOTES}

1. A rational choice perspective would emphasise that the incentives to 'join in' are not large given that the likelihood that an individual's involvement would be important, crucial or pivotal is negligible. And in cases of collective benefits, individuals might choose to freeride on the basis that others will incur the costs of participation to secure the good.

2. It is also worth noting that the notion of a democratic deficit is a relatively recent phenomenon. As Majone (1998: 12) highlights, the prevailing view (that is, before the Single European Act and the Maastricht Treaty) was that 'the integration process derives its legitimation from the democratic character of the (sovereign democratic) Member States'.

3. Clearly the civil society concept has much elasticity (for a detailed analysis see Chapter 2, by Zimmer and Freise).

4. Council Decision of 26 January 2004 (2004/100/EC) Art. 1 (b).

5. See the article by Dan Bilefski 'Critics urge openness for merchants of influence' in the International Herald Tribune of 29 October 2005.

6. Of course for some, active involvement is a benefit of membership.

7. Jordan and Maloney (2007: 158f) also cite similar evidence of staff dominance and the attractiveness of passivity for members of campaign groups in the UK. A representative of the Council for the Protection of Rural England (CPRE) argued that the council positively encourages active involvement, but many members view this as an additional cost (that may lead to exit). The CPRE representative said the organisation treads very carefully in trying to activate supporters: 'We think we'd lose them if we did that [press for more active membership] because they're people who want to give money and they don't want to do any more than that ... My remit has been to develop a supporter base as opposed to a member base. It's much easier to recruit people who just want to pay money than recruit individuals into an organisation where they potentially see it as a timerelated activity which they don't have time to do basically ... So the whole task [of recruiting people] has to be geared around saying "oh don't worry, we're not expecting you to come to meetings and things, we just want your support".'

8. Grande (2002: 130) makes the point that professionalised representation in the EU could be 'justified for reasons of system effectiveness, but the democratic quality of their activities is dubious from the perspective of both representative and participatory models of democracy' (quoted in Saurugger, forthcoming 2009).

9. There is also the 'danger' that patronage may affect the tactics, strategies and policy positions of groups. Groups heavily reliant on patronage may not want to engage in activities that may be frowned upon by their sponsor or occupy policy positions too distant from the major funder's standpoint. 
10. An extensive discussion of the concept 'European Governance' is presented by Smismans (2006).

11. For extensive overviews of the various approaches to the role of interest groups and civil society organisations in European democratic decision-making processes, see Eising (2000) or Mair (2005).

12. The discussion paper argued that in its broadest sense the NGO term could subsume trade unions and business or professional organisations. However, the document was dealing 'primarily with organisations active in the so-called "Third Sector", i.e. in the non-governmental and non-economic field' (Commission of the European Communities 2000: 4).

13. Warren (2001: 10) cites van Til's (2000) estimate that ' 77.5 percent of nonprofit expenditures and 64 percent of nonprofit employment [in the USA] are within associations that act as much like for-profit organizations in that they pursue economic interests within competitive markets' (see also Jordan and Maloney 2007).

14. We are well aware that there is a 'dark side to social capital' and that there are other 'democratic pathologies' associated with groups. The aim of this section is simply to outline the potential positive contribution that NGOs could make to democracy in the EU (largely, but not wholly, from the Commission's perspective).

\section{REFERENCES}

Bauer, M. (2002) 'Limitations to agency control in European Union policy-making: The commission and the poverty programmes' Journal of Common Market Studies 40 (2), 381-400.

Blühdorn, I. (2007) 'The participatory revolution: New social movements and civil society', in K. Larres (ed.) A companion to Europe since 1945, London: Blackwell Publishing.

Chaskin, R.J. (2003) 'Fostering neighborhood democracy: Legitimacy and accountability within loosely coupled systems' Nonprofit and Voluntary Sector Quarterly 32 (2), 161-89.

Commission of the European Communities (CEC) (2000) The Commission and non-governmental organizations: Building a stronger partnership, Commission Discussion Paper, 18 January 2000, Brussels: CEC.

Commission of the European Communities (CEC) (2001) European governance: $A$ white paper, 25 July 2001 COM(2001) 428 final, Brussels: CEC.

Crenson, M.A. and Ginsberg, B. (2002) Downsizing democracy: How America sidelined its citizens and privatized its public, Baltimore: The Johns Hopkins University Press.

Eising, R. (2000) Assoziative Demokratie in der Europäischen Union, Polis 47, Hagen: Institut für Politikwissenschaft.

Friedrich, D. (2007) Old wine in new bottles? The actual and potential contribution of civil society organisations to democratic governance in Europe, RECON Online Working Paper 2007/08, July 2007, www.reconproject.eu/main.php/RECON_ wp_0708.pdf? fileitem $=5456965$, last access: 16 October 2007.

Grande, E. (2002) 'Post-national democracy in Europe', in M.T. Greven and L.W. Pauly (eds) Democracy beyond the state? The European dilemma and the emerging global order, Lanham: Rowman and Littlefield, pp. 115-38.

Grant, W. (2002) 'Civil society and the internal democracy of interest groups', paper prepared for the Political Studies Association of the United Kingdom Annual Conference, Aberdeen, April. 
Graziano, P. and Vink, M.P. (2007) Europeanization: New research agendas, Basingstoke: Palgrave Macmillan.

Greenwood, J. (2007) 'Review article: Organized civil society and democratic legitimacy in the European Union' British Journal of Political Science 37 (2), 333-57.

Jordan, G. and Maloney, W.A. (2007) Democracy and interest groups: Enhancing participation? Basingstoke: Palgrave Macmillan.

Mair, P. (2005) Popular democracy and the European Union polity, European Governance Papers, www.connex-network.org/eurogor/pdf/egp-connex-c-0503.pdf, last access: 16 October 2007.

Majone, G. (1998) 'Europe's 'democratic deficit': The question of standards' European Law Journal 4 (1), 5-28.

Michalowitz, I. (2004) 'Analysing structured paths of lobbying behaviour: Why discussing the involvement of "civil society" does not solve the EU's democratic deficit' European Integration 26 (2), 145-70.

Nanz, P. and Steffek, J. (2005) 'Assessing the democratic quality of deliberation in international governance: criteria and research strategies' Acta Politica 40 (3), 368-83.

Noll, H.-H. and Scheuer, A. (2006) 'Kein Herz für Europa?' Informationsdienst Soziale Indikatoren 35, 1-5.

Putnam, R.D. (1993) Making democracy work: Civic traditions in modern Italy, Princeton, NJ: Princeton University Press.

Putnam, R.D. (1995) 'Bowling alone: America's declining social capital' Journal of Democracy 6 (1), 65-78.

Putnam, R.D. (2000) Bowling Alone: The collapse and revival of American community, New York: Simon and Schuster.

Saurugger, S. (2007) 'Democratic 'misfit'? Conceptions of civil society participation in France and the European Union' Political Studies 55 (2), 384 404.

Saurugger, S. (forthcoming 2009) 'Associations and democracy in the European Union' West European Politics.

Scholte, J.A. (1999) Global civil society: Changing the world? Centre for the Study of Globalisation and Regionalisation (CSGR), Working Paper No. 31/99, Coventry: University of Warwick.

Skocpol, T. (2003) Diminished democracy: From membership to management in American civic life, Oklahoma: University of Oklahoma Press.

Smismans, S. (2006) 'Civil society and European governance: From concepts to research agenda', in S. Smismans (ed.) Civil society and legitimate European governance, Cheltenham: Edward Elgar, pp. 3-19.

Sudbery, I. (2003) 'Bridging the legitimacy gap in the EU: Can civil society help to bring the Union closer to its citizens?' Collegium 26, 75-95.

Truman, D.B. (1951) The governmental process: Public interests and public opinion, New York: Alfred A Knopf.

van Til, J. (2000) Growing civil society: From nonprofit sector to third space, Indiana: Indiana University Press.

Warleigh, A. (2001) "Europeanizing" civil society: NGOs as agents of political socialization' Journal of Common Market Studies 39 (4), 619-39.

Warren, M.E. (2001) Democracy and association, Princeton, NJ: Princeton University Press. 